\title{
The Relationship and Integration of Museum Curriculum and Traditional Curriculum
}

\author{
Shuyan Pei \\ School of Historical Culture and Tourism \\ Xi'an University \\ Xi'an, China 710065
}

\author{
Xiao Que \\ School of Historical Culture and Tourism \\ Xi'an University \\ Xi'an, China 710065
}

\begin{abstract}
In recent years, the educational function of museums has gradually attracted the attention of the society. It has become a hot topic to explore the use of museum educational resources to achieve museum education. From the perspective of museum education development, this paper discusses the relationship between museum curriculum and traditional curriculum, so as to better promote the integration of museum curriculum and traditional curriculum, and give full play to the educational role of museums.
\end{abstract}

Keywords—museum; education; youth; practice

\section{INTRODUCTION}

At present, with the continuous development of the museum cause, the educational function of the museum has gradually attracted the attention of the state and society, and the museum curriculum developed for schools has gradually become an important form of museum education. To explore the relationship between the museum curriculum and the traditional curriculum and promote their better integration will be an important part of the development of museum education, so that museum resources play an important role in school education.

\section{EDUCATIONAL FUNCTION OF MUSEUMS AND MuSEUM REGULATIONS}

For a long time, as a treasure house of collecting and displaying human material and intangible civilization, the museum has rich exhibits. Its main functions mainly include collection, display, protection and research. As an important social education institution, museum plays an important role in complementing and improving education.

Since 2019, with the continuous development of museum culture and the introduction of relevant policies, as well as the improvement of social attention to the educational function of museums, the development direction of contemporary museums is no longer simply to display and collect cultural relics, but more inclined to serve the public and society, provide knowledge and education for the public, guide the public to establish a correct view of history and values, and fully develop the educational function of the museum

The museum regulations issued in 2015 is the first national regulatory document in China's museum industry, which points out the direction of museum development in the new era. As everyone knows, the museum is a non-profit organization. One of its main purposes is to carry out popular science education and knowledge dissemination. The new "Museum Regulations" put more emphasis on the purpose of "education". In the second article of the first chapter "General Provisions" of the "Museum Regulations", it is clearly pointed out that "the museum as mentioned in the Museum Regulations refers to the non-profit organization registered by the registration authority in accordance with the law for the purpose of education, research and appreciation, collecting, protecting and displaying the witness of human activities and natural environment to the public." It can be seen that the purpose of "education" of museums is put in the first place, and the importance of the purpose of "education" of museums is fully emphasized. In the earlier definition of museums, "research, education and appreciation are the purposes", and education is put in the second place. The "Museum Regulations" clarify the purpose of museums and are consistent with the purpose of ICOM for museum operation. [1]

In Article 34 of the Museum Regulations, it is proposed that "museums should use modern information technology to carry out various and lively social education and service activities, and participate in community cultural construction and foreign cultural exchange and cooperation according to their own characteristics and conditions." [2] This requires that on the one hand, museums should open their doors and vigorously carry out social education and cooperation and service activities for the society; on the other hand, it is necessary to enter the society and participate in community cultural construction; at the same time, it is also necessary to go to the world and participate in foreign cultural exchanges and cooperation, which is a higher requirement of the state for museums from the legal level.

In addition, Article 35 of the "Museum Regulations" points out that the administrative department for education should "formulate policies and measures with the use of museum resources to carry out education, teaching and social practice activities"; at the same time, the museum should "provide support and help for schools in carrying out various education and teaching activities". It points out that museum education should be combined with school education. 
According to the national laws and regulations of the museum industry, the state has made a new adjustment to the order of the three basic functions of the museum, clearly putting education in the first place among the basic functions of the museum, which will have a long-term impact on the future development and operation of the museum.

\section{DEFINITION OF MUSEUM CURRICULUM}

Under the guidance of relevant policies, museum education is gradually warming up. However, there is still a common misunderstanding about the concept of museum education in the society. It is simple to equate visiting museums with museum education. In fact, museum education is not the same as visiting a museum, but must be based on exhibitions to re-develop the curriculum. The development of museums for adults should be improved into the museum curriculum for teenagers.

Museum curriculum mainly aims at adolescents aged 7 to 18. Students in this stage are the hope of the nation, and are the most common group that museum education strives for. In the current environment of examination-oriented education, the museum curriculum is not a compulsory course, and the effect of museum education can't be immediately shown in the examination and enrollment. [3] The museum curriculum plays an important role in improving students' comprehensive quality, establishing correct values and historical views, learning historical knowledge and traditional culture. The students in this age group have strong learning ability and plasticity, and museum curriculum can play an active role in imperceptible influence. It can be seen that museum curriculum plays an important role in education for teenagers.

There are many ways to realize the education based on museum. For example, the most direct way is to visit the museum and explain the exhibits; or to carry out experiential activities in the museum exhibition hall, such as the activity "feeling ancient buildings and building the future together" in Shanxi Museum. Through the experiential education mode, the visitors jointly build the ancient architectural model of China, learn the relevant knowledge of ancient architecture, and understand the cultural background of ancient buildings in different periods. There are also many ways such as opening academic and popular science lectures in museums.

However, these museum education methods, which are completely separated from schools and educational institutions, lack a systematic education system, and often only carry out independent activities. They are too fragmented and entertaining, difficult to achieve the ideal education effect. Therefore, in view of the current situation of museum education development, museums should cooperate with schools and other educational institutions to explore and practice, and take the museum curriculum developed in combination with traditional curriculum as the main mode of museum education.

For a long time, as a subsidiary tool of school education, it is difficult for museums to give full play to the real educational role. In order to make full use of the unique value and characteristics of museum education, it is necessary to promote museum education to the same important position as that of school education. Museum education should be integrated into school curriculum teaching, mainly in the form of traditional courses and supplemented by museum visiting and practice. At the same time, it can develop museum curriculum that is consistent with the learning stage for students of different ages, systematically develop courseware, lesson plans, teaching materials and teaching tools with different themes and difficulties. It is possible to add new and interesting museum contents to the traditional curriculum model, and establish a complete museum education system.

As early as 2014, the State Administration of Cultural Relics issued the "pilot program for improving the adolescent educational function of museum", in which it was mentioned that "in accordance with the educational concept of "focusing on participation, process and experience", the design and development of youth curriculum of museum is closely combined with the national curriculum, local curriculum and school-based curriculum setting and curriculum reform objectives. The museum education curriculum should cover subject curriculum and integrated curriculum, and be carefully designed according to the four levels of kindergarten, lower primary school, higher primary school and junior high school, so as to build the teaching objectives, teaching focus, experience content and evaluation standards of each stage. The museum education curriculum should design teaching auxiliary materials, three-dimensional learning materials package, teaching reference materials package, electronic courses, etc. corresponding to the curriculum, and be integrated in curriculum teaching of primary and secondary schools, finally establishing a longterm mechanism for primary and secondary school students to participate in museum education activities." [4] It can be seen that the state also provides support for the development of museum curriculum in terms of policy.

\section{THE RELATIONSHIP BETWEEN MUSEUM CURRICULUM AND TRADITIONAL CURRICULUM}

To sum up, the integration of museum curriculum and traditional curriculum plays a complementary role.

The museum has rich educational resources with various contents and forms. The curriculum of museum education resources can effectively make up for the shortcomings of traditional exam-oriented education. Through the processing and creation of material and intangible resources of the museum, it can develop and make corresponding courses in schools, so that more students can receive museum education in traditional courses. The rich and colorful museum education resources can fully cover the Chinese, mathematics, society, nature, music, art and other disciplines of school education, and make use of the relevance between disciplines to generate new cognition. At the same time, the contents of the museum curriculum will also intersect with the teaching contents of the school, so that students can have a more comprehensive understanding of the required courses of the school through the study of the museum curriculum. [5] 
The traditional curriculum focuses on teachers, teaching materials and classrooms and pays attention to the systematic and hierarchical teaching of knowledge. The classroom is dominated by teachers, and students are the recipients of knowledge. The examination results directly reflect the learning situation. Promoting the teaching progress step by step can effectively complete the curriculum progress. But this kind of teaching mode is often boring when teaching the exam-oriented subject. It is difficult for students to be interested in courses based on single theory and lack of practice. In addition, faced with the pressure of exams, many students tend to resist traditional courses and have a negative attitude towards learning.

By analyzing the characteristics of museum curriculum and traditional curriculum, making rational use of the advantages of both sides, developing the advantages and avoiding the disadvantages, giving full play to the comprehensive advantages and organically combining museum education content with traditional curriculum mode are inevitable results in the development of social education. The museum has material resources and intangible resources that other educational institutions do not have. The traditional education system of the school has rich teaching experience and research results on students' psychology. The organic combination and complementary advantages of the two can effectively make up for the shortcomings of traditional education. In the process of complementing and promoting each other between museum education and traditional education, museum curriculum will be improved day by day to promote the overall development of students' comprehensive ability in quality education. [6]

\section{INTEGRATION OF MUSEUM CURRICULUM AND TRADITIONAL CURRICULUM}

The integration of museum curriculum and traditional curriculum is an important part of promoting museum education to enter the campus. The following ideas are proposed for the development and construction of curriculum:

\section{A. Carrying out In-depth Investigation and Analysis, and Making Targeted Development of Curriculum}

In order to ensure the quality and level of museum curriculum development and the effective and reasonable use of museum resources, it is necessary to conduct in-depth investigation and research before curriculum development. The curriculum should be planned and oriented for the students of different regions, different age groups and different education. When designing the curriculum, students' preferences and age characteristics should be considered, innovative activity forms and contents should be actively explored, and targeted museum courses should be developed.

In the process of curriculum development, it should attach importance to curriculum design based on museum resources, embed museum curriculum under the framework of traditional curriculum, increase interesting links and creative activities under the guarantee of sufficient classroom teaching time, and mobilize the enthusiasm and attention of students. The development process should be based on the syllabus teaching plan, making courseware and audio materials, preparing teaching equipment in advance and conducting multiple trial lectures, so as to be familiar with the course content and grasp the length of class. Only after the ideal effect is achieved, it can be applied in classroom teaching. At the same time, it is necessary to adhere to the standardized development of curriculum, and ensure the quality of museum curriculum development.

\section{B. Making Full Use of Museum Resources and Developing Unique Curriculum Content}

A large number of cultural relics collected and displayed in the museum are of great educational, scientific, historical or artistic value, and are unique compared with traditional educational resources. In the process of designing museum curriculum, it should combine the uniqueness of museum resources with traditional school curriculum, making them fully integrated and unified in the classroom, stimulating new enthusiasm for learning, and making learning more vivid and interesting, and more effective. This kind of cooperation is a positive and creative process. [7]

\section{Strengthening Discipline Integration}

The rich educational resources of the museum can intersect with the compulsory courses of the school to a certain extent, and resonate with many subjects such as history, nature, art and so on. The museum curriculum should use the inter-disciplinary relevance to generate new cognition, infiltrate the knowledge of the exam-oriented curriculum into the museum curriculum, carry out cooperative teaching with the school, visualize the scientific knowledge, which are conducive to the understanding, mastery and memory of the students, will improve the scientific ability and innovation ability of the students, and help the students better adapt to the talent requirements for the development of China. [8]

\section{Expanding Innovation and Enriching Curriculum Forms}

In order to achieve the effect of complementing each other's advantages and avoiding disadvantages, the integration of museum curriculum and traditional curriculum should avoid the disadvantages of traditional curriculum. In the process of designing curriculum, it should adhere to the thinking of opening up and innovation, conduct in-depth research and excavation of museum collections, and design comprehensive practical curriculum. In view of the characteristics of young students, such as broad interest, strong desire for performance, active discovery and participation in the completion of tasks, it can really stimulate students' interest in learning, promote them to internalize knowledge automatically and consciously, build their own knowledge system, so as to cultivate their comprehensive literacy and improve their comprehensive ability. [9] In the curriculum, the contents such as the exhibition of cultural relics (reproductions), experience of cultural relics, dissemination of museum knowledge and historical knowledge, and exploration of archaeology are added, and the advantages of museum resources are flexibly 
and diversely used to mobilize the enthusiasm of students through physical objects, pictures, video materials and practical activities. For example, when teaching the contents of ancient pottery, the students will be given clay kneaded ware to experience the making of pottery. In the course of cultural relic restoration, the students will be invited to participate in the restoration of broken pottery. When introducing the field archaeological work, the students will be shown the professional tools used in archaeological excavation ... By innovating the content and enriching the form of the course, students can be guided to experience and think deeply, so as to improve their knowledge level and ideological level.

\section{E. Gathering Strength, Cooperation and Exchange}

With the continuous and in-depth development of museum education, it is very important to establish a benign educational interaction mechanism between museum and school, which can make museum education and school education achieve integration and complement each other in the fundamental goal. In the process of cooperation with schools and other educational institutions, it is necessary for museums to have full communication in advance. The school has relatively fixed educational objectives and curriculum arrangements set in accordance with the age of students, and different needs and plans for the development of museum curriculum. All of these require the museum to communicate with the school in advance, so as to provide projects to meet its needs, formulate corresponding plans, and solve related problems. Through full communication, museums and schools can set up common educational goals, develop corresponding museum curriculum and produce satisfactory educational results. [10]

\section{ON-THE-SPOT TEACHING OF MUSEUM CURRICULUM OF TONGCHEWAN PRIMARY SCHOOL IN MAY 2019}

In order to respond to the call of national policies for the development of museum education and museum curriculum, improve the understanding of students in poor areas on museum education and civilized etiquette, stimulate and cultivate students' interest in China's cultural heritage, Chinese civilization and other aspects, make students in poor areas enjoy museum education in the same way, the students majoring in cultural relics and museum of School of Historical Culture and Tourism, Xi'an University went to Tongchewan primary school in Ningshan County, Ankang City, Shaanxi Province to carry out an activity with the theme of "museum education and civilized etiquette" to enter the rural campus on May 14, 2019. ("Fig. 1")

In order to prepare three lively museum courses, the students majoring in cultural relics and museum began to design courses, make courseware and purchase teaching aids more than two months in advance. During the two months, they continued to revise and give lectures repeatedly. They insisted on integrating museum curriculum with traditional curriculum, and developed curriculums with different contents and difficulties for the third, fourth and fifth grades of primary schools in poor villages.
After full communication with the local school, the curriculum project team developed three museum courses: "museum you don't know", "story behind the museum", "the culture of Tang Dynasty and ancient terracotta warriors", which was taught by students majoring in cultural relics and museum. In the 40 minute course, a wealth of pictures and audio materials were embedded, including the materials of archaeological excavation, cultural relics replicas and professional tools of archaeological work, and a large number of cultural and creative products of museum and stationery are purchased as prizes for students. The practical teaching of this course provides an effective case for the combination of museum curriculum and traditional curriculum.

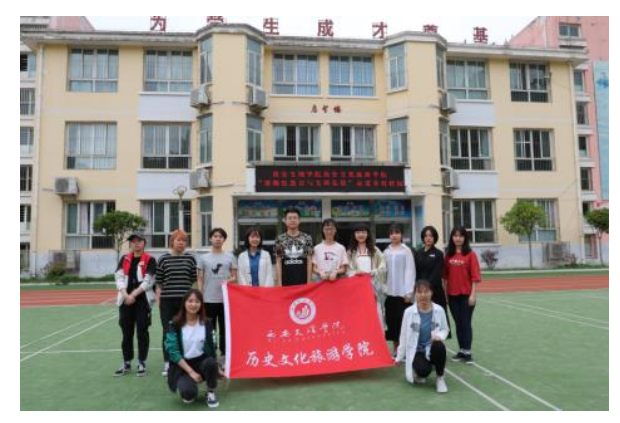

Fig. 1. The students majoring in cultural relics and museum of School of Historical Culture and Tournism, Xi'an University went to Tongchewan primary school to teach.

Taking the lesson "the story behind the museum" as an example, this paper analyzes the organic combination of museum curriculum and traditional curriculum.

\section{A. Instruction of Teaching Design}

\section{- Content description}

The teaching purpose of this course is to explore the working process of cultural relics from the archaeological site to the museum and show the specific process of cultural relics restoration, so as to enrich students' knowledge accumulation, broaden students' knowledge field, increase students' understanding of cultural relics work and improve their interest in the museum learning.

- Grade

Fifth Grade of primary school

- Teaching hours

1 class (40 minutes)

- Preparation before class

Making courseware, learning about relevant materials, and preparing teaching tools

\section{B. Teaching Objectives}

- Let students get an overview of the basic processes of archaeological excavations and the significance of archaeological work. 


\section{A Summary of Course}

With trial lectures in the early stage, the museum methods and processes of cultural relics restoration through the practice of cultural relics restoration process.

- Increasing students' interest in museums, stimulating learning enthusiasm, and expanding knowledge.

\section{The Introduction of the Teaching Process}

- Displaying four pictures "Pink Pasted Peach Pattern", "Golden Phoenix Hairpin", "Bronze Bracelet" and "Blue Hemispheric Glass Bubble", and introducing the course theme. ("Fig. 2")

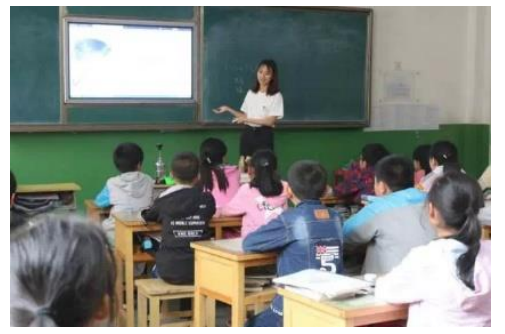

Fig. 2. Teaching process.

- Let the students discuss and answer the question "What does the cultural relics experience and then appear in the museum?"

- Explaining the basic process of archaeological excavation through rich graphics and texts, and showing students the professional tools and equipment for archaeological excavation.

- Playing the video of repairing the fragments of the Tang tri-color glazed ceramic horse of the program "I am in the Forbidden City to repair cultural relics", and introducing the theme of the course into the restoration of cultural relics.

- Practicing the process of ceramic restoration work on site and inviting students to participate. ("Fig. 3")

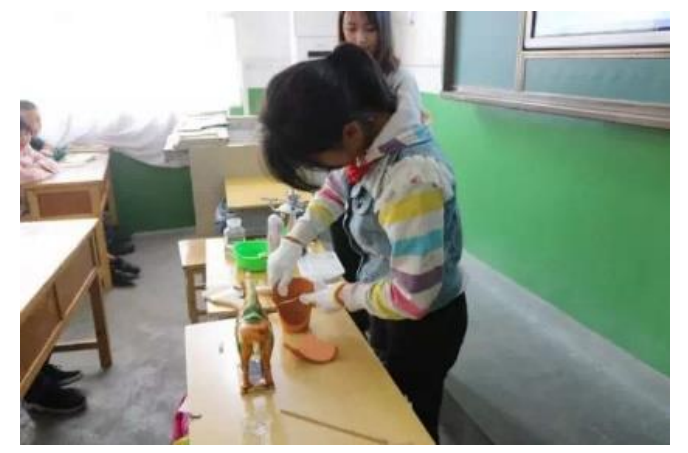

Fig. 3. Students experience ceramic restorations.

- Guiding students to share their feelings and end the course.

curriculum went smoothly and completed all the contents planned in advance within the specified time. The students have a high degree of enthusiasm and activity. The students who actively participated in and listened to the lectures in the Q\&A session were rewarded, greatly motivating the students. In order to gain a deeper understanding of the impact of the course on the students and the quality of the course, the team produced relevant course evaluation questionnaires for the students to fill out, summarized the evaluation data and recommendations, and provided relevant information for the development of new courses for the future.

\section{CONCLUSION}

The integration of museum curriculum and traditional curriculum is the inevitable result of the development of museum education. According to the characteristics of museum curriculum and traditional curriculum, it is necessary to make rational use of the superior resources of both sides. And then, the museum curriculum will become more and more perfect. It is possible to promote the development of museum education, and the museum becomes a instructor in the growth and education of the youth.

\section{REFERENCES}

[1] Meng Qingjin. The Museum Regulations indicate the direction for future development [N]. China Cultural Relics, 2015-3-24: Fourth edition. (in Chinese)

[2] State Council of the People's Republic of China. Museum Regulations (Order No. 659 of the State Council) [Z], 2015-1-14. (in Chinese)

[3] Guo Qingsheng. Stimulating learning motivation and cultivating scientific spirit: Discussion on teaching methods of the museum curriculum [J]. Science Education and Museum, 2018(3):157. (in Chinese)

[4] State Administration of Cultural Heritage. The State Administration of Cultural Heritage carried out the work of "Improving the pilot function of museum youth education" [N]. China Cultural Relics, 2014-01-24: first edition. (in Chinese)

[5] Dong Chenyang. Analysis on the organic combination of museum resources and school-based curriculum [J]. Inner Mongolia Education, 2017-09: 122. (in Chinese)

[6] Liu Fang. Research on the integration and utilization of museum education and school education [J]. Science and Technology Journal, 2018-02 (below), sixth edition: 179. (in Chinese)

[7] Liu Fang. Research on the integration and utilization of museum education and school education [J]. Science and Technology Journal, 2018-02 (below), sixth edition: 179. (in Chinese)

[8] Li Feng. The mechanism and strategy of combining digital museum with school education [J]. Marketing, 2019, 21: 71. (in Chinese)

[9] Liu Li, Li Honglong, Wang Meng, Li Xiaodan. Research on the interaction mechanism between museum and school based on student education [J]. Heritage and Protection Research, 2019, No. 3: 24. (in Chinese)

[10] Guo Meixia. On the cooperation between museums and schools: the development of new partnerships. Chinese Museum [J]. 2017, No. 2: 6. (in Chinese) 